\title{
Inhaltsverzeichnis / Contents
}

\author{
Band / Volume \\ 1 \\ Geleitwort vii \\ Hinweise für den Benutzer viii \\ Introduction $\mathrm{xi}$ \\ Notes on Use xii \\ Quellenverzeichnis xv
}

List of Sources $x v$

A - L

Band / Volume

2

$\mathrm{M}-\mathrm{Z}$

Namenregister nach Archiven 619

Name Index to Archives 619 
